\title{
Heavy metal and Al bioaccumulation in the anemone Actinia equina Linnaeus, 1758 (Cnidaria: Actiniidae) from İskenderun Bay, North-Eastern Mediterranean, Turkey
}

\section{İskenderun Körfezi (Kuzeydoğu Akdeniz, Türkiye) anemonu Actinia equina Linnaeus, 1758 (Cnidaria: Actiniidae)'da ağır metal ve Al birikimi}

\author{
Önder Duysak ${ }^{\text {** }}$ • Yavuz Mazlum² • Erkan Uğurlu³ \\ ${ }^{1}$ Iskenderun Technical University, Faculty of Marine Sciences and Technology, 31200 İskenderun, Hatay, Turkey \\ 2 Isskenderun Technical University, Faculty of Marine Sciences and Technology, 31200 İskenderun, Hatay, Turkey \\ ${ }^{3}$ Iskenderun Technical University, Faculty of Marine Sciences and Technology, 31200 Iskenderun, Hatay, Turkey
}

https://orcid.org/0000-0002-7484-3102

https://orcid.org/0000-0002-9547-0966

(D) https://orcid.org/0000-0001-8940-8421

Duysak, Ö., Mazlum, Y. \& Uğurlu, E. (2021). Heavy metal and Al bioaccumulation in the anemone Actinia equina Linnaeus, 1758 (Cnidaria: Actiniidae) from İskenderun Bay, North-Eastern Mediterranean, Turkey. Ege Journal of Fisheries and Aquatic Sciences, 38(2), 161-166. DOI: 10.12714/egejfas.38.2.04

Abstract: The purpose of this study was to determine the accumulation levels of ten metals ( $\mathrm{Fe}, \mathrm{Zn}, \mathrm{Cd}, \mathrm{Cu}, \mathrm{Co}, \mathrm{Ni}, \mathrm{Al}, \mathrm{Mn}, \mathrm{Pb}$, and $\mathrm{Cr}$ ) in the muscle tissues of Actina equina indvduals. A total of 120 individuals of $A$. equina were collected at six different stations in İsenderun Bay in spring 2013. The accumulation levels of heavy metals in the tissues were found to vary significantly among stations. The mean concentrations of Fe were the highest at Samandağ station $(105.11 \pm 74.28 \mathrm{mg} / \mathrm{kg})$ whereas the lowest average value of Co $(0.84 \pm 0.10 \mathrm{mg} / \mathrm{kg})$ was obtained at Dörtyol station. Heavy metal concentratıons in muscle tissue of $A$. equina were ordered as $\mathrm{Fe}>\mathrm{Zn}>\mathrm{Mn}>\mathrm{A} \mid>\mathrm{Cr}>\mathrm{Cu}>\mathrm{Pb}>\mathrm{Ni}>\mathrm{Cd}>\mathrm{Co}$, respectively. This study is the first detailed bioaccumulation study conducted with A. equina in İskenderun Bay.

Keywords: Actinia equina, heavy metal, ìskenderun Bay, North-Eastern Mediterranean

Öz: Bu çalışmanın amacı, Actinia equina bireylerinin kas dokularında on metalin ( $\mathrm{Fe}, \mathrm{Zn}, \mathrm{Cd}, \mathrm{Cu}, \mathrm{Co}, \mathrm{Ni}, \mathrm{Al}, \mathrm{Mn}, \mathrm{Pb}$ ve $\mathrm{Cr}$ ) birikim düzeylerini belirlemektir. 2013 ilkbaharında İskenderun Körfezi'nde altı farklı istasyonda toplam 120 A. equina birey toplanmıștır. Dokulardaki ağır metal birikim seviyeleri istasyonlar arasında önemli farkllıklar göstermiştir. Ortalama Fe konsantrasyonu en yüksek Samandağ istasyonunda $(105,11 \pm 74,28 \mathrm{mg} / \mathrm{kg})$, en düşük ortalama Co $(0,84 \pm 0,10 \mathrm{mg} / \mathrm{kg})$ Dörtyol istasyonundan elde edilmiştir. A. equina kas dokusundaki ağır metal konsantrasyonları sırasılyla $\mathrm{Fe}>\mathrm{Zn}>\mathrm{Mn}>\mathrm{Al}>\mathrm{Cr}>\mathrm{Cu}>\mathrm{Pb}>$ $\mathrm{Ni}>\mathrm{Cd}>\mathrm{Co}$ şeklinde bulundu. Bu çalışma, İskenderun Körfezi'nde A. equina ile yapılan ilk ayrıntılı biyoakümülasyon çalışmasıdır.

Anahtar kelimeler: Actinia equina, ağır metal, İskenderun Körfezi, Kuzeydoğu Akdeniz

\section{INTRODUCTION}

Today, there is a continuous increase in the world population and intensive industrial development. This rapid growth gradually causes industrialization and population growth and consequently environmental pollution. Heavy metals, as one of the pollutants that are dangerous for marine environments and can harm human health, reach the sea as a result of various processes and cycles, and settle on the sea bottom. Sources of heavy metals that enter or exit in the marine environment are of natural or artificial origin. Natural contamination can be caused by rivers and erosions, as well as by volcanic movements on the seabed and atmospheric convection. The concentrations of artificially originated heavy metals in marine environments increase today as a result of industrial activities, agricultural activities, mining, refinery facilities, excessive consumption of fossil fuels, use of metal products in agriculture, and anthropogenic activities such as sea transportation (Anonymous, 2008).

İskenderun Bay is located in the eastern part of the Northeastern Mediterranean Sea and has an average depth of approximately $70 \mathrm{~m}$ when it has richer resources than other regions (Kosswing, 1953). İskenderun Bay is characterized having dense industrial establishments (iron steel factory, petrochemical industry, fertilizer industry, etc.), fishing, transportation, and urbanization. Due to its in and outer currents systems, pollutants resulting from above activities are spreading into bay and they lead it having a potential risk of pollution (Can et al., 2019). Also, in addition to the agricultural pollutants carried by the Seyhan and Ceyhan rivers, the increasing domestic wastes in the recreation areas in the summer season when the population doubles, thus increasing the pollution load (Anonymous, 1997; Duysak and Azdural, 2017).

The use of biological indicators to assess levels of pollutants especially trace metals in marine coastal ecosystems is very common nowadays. Marine organisms that receive dissolved and particulate metals can be used as an indicator of the bioavailability of a particular pollutant over time (Phillips and Segar, 1986; Rainbow and Phillips, 1993; Volterra and Conti, 2000). The animals living in aquatic areas 
accumulate heavy metals $1.000-10.000$ times more in their bodies when their living medium, the density of the water, and the nutrition chain are considered (Ekici and Yarsan, 2009). In temperate coastal communities, anemones are often the prominent members of the fauna. Actinia-type sea anemones are small-sized creatures and form large populations in a particular region (Sole-Cava and Thorpe, 1992). Members of this species are opportunistic omnivorous suspension feeders (Ormond and Caldwell, 1982). Since they have relatively short tentacles, they cannot actively search for prey and therefore feed on organisms or organic debris falling into their oral discs (Chintiroglou and Koukouras, 1992). This species is also highly tolerant of environmental variables such as extreme temperature and extreme salinity (Fish and Fish, 2011). The typical lifespan of $A$. equina under natural conditions is about three years (Fish and Fish, 2011). Sea anemone Actinia equina Linnaeus, 1758 which can be easily collected from their environment due to their sedentary life (Perrin et al. 1999), is used as a bioindicator species in heavy metal studies (Gadelha et al., 2010; Harland et al., 1990). Another reason for the use of marine anemones as bioindicators is their long life (Denny and Gaines, 2007).

In recent years, marine invertebrates have been used in the bioaccumulation studies conducted in the Bay of İskenderun. Mollusca (mollusca) is also observed in these studies (Turkmen and Türkmen, 2005; Yuzereroglu et al., 2010; Duysak and Ersoy, 2014; Duysak and Azdural, 2017). No bioaccumulation studies of $A$. equina species were found in the Bay of İskenderun. In this study, A. equina is also distributed in the coastal region of İskenderun to a depth of 15 meters in the coastal region. These animals are immobilized and are exposed to all discharges. Therefore, it is aimed to determine the accumulation of heavy metal levels in these species and to determine whether this species can be used in the biomonitoring studies carried out in İskenderun Bay which is exposed to various types of pollution. At the same time, this study is the most comprehensive heavy metal accumulation study ever made in the Bay of İskenderun for $A$. equina species.

\section{MATERIAL AND METHODS}

\section{Sample preparation}

Actinia equina individuals have been observed throughout the year from six different stations in İskenderun Bay (Figure 1), at a depth of 1-5 m, especially in ecosystems with a rocky substrate with high water movements. In the spring season (March-May 2013) when the anemone population was dense and the weather and sea conditions were suitable (since it can be collected by free diving), 20 samples were taken from each station and a total of $120 \mathrm{~A}$. equina samples were collected. $A$. equina individuals were collected by scraping the hard rocks (1-5 m depth) with the help of plastic knives and spatulas. The collected samples were brought to the laboratory for storage in the cold chain. Morphometric measurements of the collected individuals were taken and their weights $(\mathrm{g})$ were weighed (Table 1).

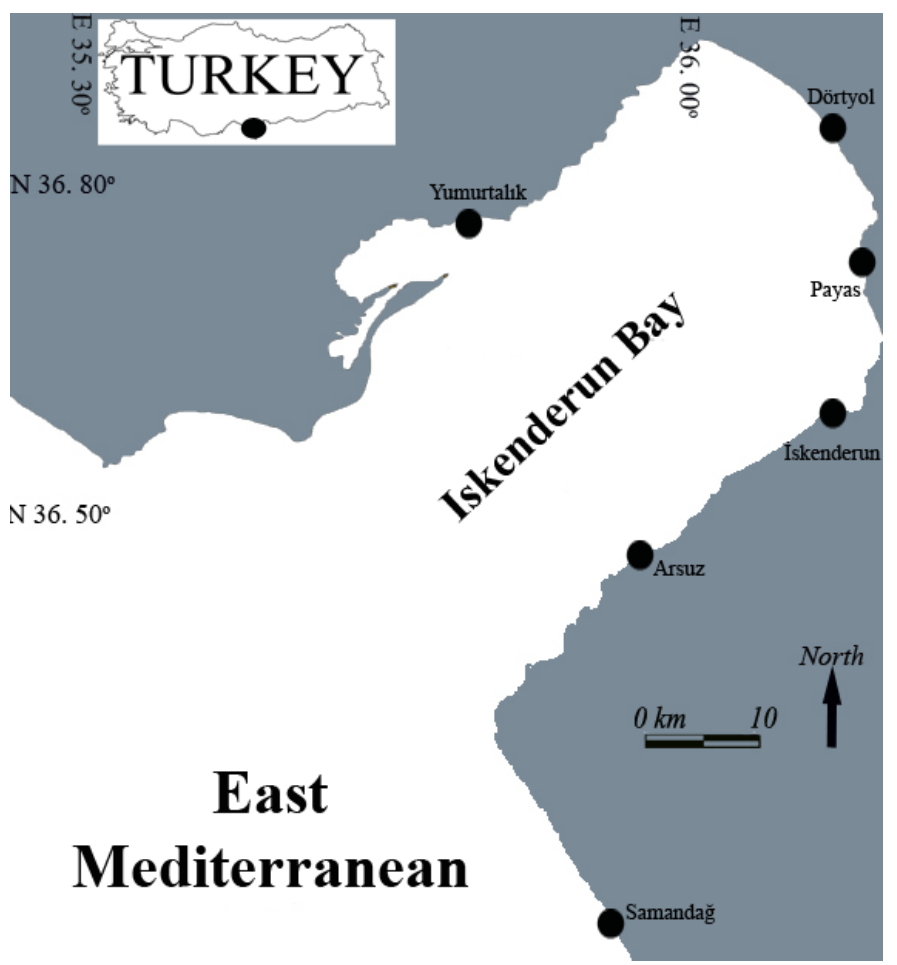

Figure 1. Map of the study area in İskenderun Bay, Turkey (modified from Simsek and Demirci, 2018) 
Table 1. Average wet weight $(\mathrm{g})$, pedal disc diameter $(\mathrm{mm})$, and height from disc to tentacle $(\mathrm{mm})$ measurements at different stations for $A$. equina

\begin{tabular}{llccc}
\hline Stations & $\mathbf{n}$ & Wet weight $(\mathrm{g})$ & Pedal disc diameter $(\mathrm{mm})$ & Height from dics to tentacle $(\mathrm{mm})$ \\
\hline Yumurtalık & 20 & $3.46 \pm 2.33$ & $25.37 \pm 6.13$ & $17.87 \pm 5.41$ \\
Dörtyol & 20 & $4.42 \pm 2.57$ & $28.22 \pm 7.69$ & $18.96 \pm 5.04$ \\
Payas & 20 & $2.37 \pm 1.30$ & $21.01 \pm 3.92$ & $15.85 \pm 5.22$ \\
İskenderun & 20 & $8.01 \pm 3.32$ & $27.17 \pm 5.38$ & $12.38 \pm 0.33$ \\
Arsuz & 20 & $2.8 \pm 1.06$ & $16.48 \pm 3.01$ & $23.75 \pm 4.45$ \\
Samandağ & 20 & $2.04 \pm 1.08$ & $15.19 \pm 2.24$ & $12.06 \pm 0.46$ \\
\hline
\end{tabular}

İskenderun Bay, where the study was conducted, has various pollution discharges such as sea transport, domestic wastes, agricultural wastes, etc., in addition to intensive industrial activities. The pollution types of the 6 selected stations are given in Table 2.

Table 2. Sampling stations and pollution loads

\begin{tabular}{ll}
\hline Station name & \multicolumn{1}{c}{ Pollution types } \\
\hline Yumurtalık & $\begin{array}{l}\text { Botaş pipeline, industrial waste, power plant, } \\
\text { using chemical fertilizer, sea traffic, port } \\
\text { activities, fishing activity } \\
\text { Oil filling facilities, iron and steel industry, } \\
\text { industrial waste, fertilizer industry, using } \\
\text { chemical fertilizer, sea traffic, port activities, } \\
\text { Dörtyol }\end{array}$ \\
$\begin{array}{l}\text { fishing activity, domestic waste } \\
\text { Payas and steel industry, industrial waste, Sea } \\
\text { traffic, port activities, fishing activity, domestic }\end{array}$ \\
$\begin{array}{l}\text { waste } \\
\text { İskenderun }\end{array}$ & $\begin{array}{l}\text { Sea traffic, tourism, industrial waste, Gübre } \\
\text { Sanayi, port activities, fishing activity, domestic }\end{array}$ \\
waste & $\begin{array}{l}\text { Using chemical fertilizer, tourism, fishing } \\
\text { activity, domestic waste }\end{array}$ \\
Samandağ & $\begin{array}{l}\text { Using chemical fertilizer, tourism, fishing } \\
\text { activity, domestic waste }\end{array}$ \\
\hline
\end{tabular}

\section{Digestion procedures}

This approach was modified from Tüzen (2003). A homogenized $2 \mathrm{~g}$ sample was placed in a $20 \mathrm{ml}$ digestion tube, and $5 \mathrm{ml}$ of high purity nitric acid (Merck) were added then the samples were heated to dissolve at $60^{\circ} \mathrm{C}$ for 7 days. After digestion, the samples were filtered through WhatmanQuantitative (No: $42,110 \mathrm{~mm} \mathrm{£)} \mathrm{filter} \mathrm{paper.} \mathrm{The} \mathrm{digested}$ portion was then diluted to a final volume of $20 \mathrm{ml}$. A blank digest was carried out in the same way. All metals were determined against aqueous standards. Digested samples were analyzed three replicates for each metal.

\section{Analytical procedures}

Determination of all metal concentrations was carried out by inductively coupled plasma atomic emission spectrometry (ICP-AES) (Varian model, Liberty Series II; Palo Alto, USA) equipment located at Mustafa Kemal University. High quality data was used for ICP-AES calibration and the absorption lines identified are given in Table 3. Purity Multi-Standard was used. Metal concentrations were calculated as $\mathrm{mg} / \mathrm{kg}$ wet weight. The quality of the data was checked by the analysis of standard reference material DORM-2 (National Research Council of Canada; dogfish muscle and liver MA-A-2/TM fish flesh). Repeated analysis of reference materials showed good accuracy with recovery rates for metals between $91 \%$ and $104 \%$. The results showed good agreement between the certified and the analytical values.

Table 3. Absorption line and detection limit of metals

\begin{tabular}{ccc}
\hline Elements & Absorption line $(\mathrm{nm})$ & Detection limit (ppm) \\
\hline $\mathrm{Fe}$ & 259.940 & 0.015 \\
$\mathrm{Zn}$ & 213.856 & 0.009 \\
$\mathrm{Cd}$ & 226.502 & 0.015 \\
$\mathrm{Cu}$ & 324.754 & 0.020 \\
$\mathrm{Co}$ & 242.5 & 0.15 \\
$\mathrm{Ni}$ & 231.1 & 0.20 \\
$\mathrm{Mn}$ & 257.610 & 0.003 \\
$\mathrm{~Pb}$ & 220.353 & 0.14 \\
$\mathrm{Cr}$ & 267.716 & 0.040 \\
\hline
\end{tabular}

\section{Statistical analysis}

All samples were collected and analyzed in duplicate and the results obtained as the mean \pm standard deviation. Oneway ANOVA and Tukey test were used to determine the significant difference between the means of metal concentration levels among the stations. All statistical calculations were done by SPSS 17.0 statistical software package. In all cases, the estimation was carried out at a significant level of 0.05 (Zar, 1984).

\section{RESULTS}

In this study, heavy metal accumulations in A. equina collected from six different stations in İskenderun Bay were investigated (Figure 1). The mean and comparison of heavy metal accumulation levels calculated from muscle tissue according to the six different stations was given in $\mathrm{mg} / \mathrm{kg}$ wet weight in Table 4 . We found that the mean concentration of heavy metals in tissues varied significantly among the stations $(p<0.05)$. 
Duysak et al., Ege Journal of Fisheries and Aquatic Sciences, 38(2), 161-166 (2021)

Table 4. Mean concentrations of heavy metals in muscle tissue of Actinia equina at six different stations (mean $\pm \mathrm{SD}$. wet weight $\mathrm{mg} / \mathrm{kg}$ )

\begin{tabular}{|c|c|c|c|c|c|c|}
\hline \multicolumn{7}{|c|}{ Stations } \\
\hline Metals & Yumurtalık & Dörtyol & Payas & İskenderun & Arsuz & Samandağ \\
\hline $\mathrm{Fe}$ & $29.89 \pm 3.91^{a}$ & $88.32 \pm 10.70^{b}$ & $78.11 \pm 18.81^{a, b}$ & $32.17 \pm 6.08^{a}$ & $57.63 \pm 17.78^{a, b}$ & $105.11 \pm 74.28 \mathrm{a}, \mathrm{b}$ \\
\hline$Z n$ & $45.47 \pm 4.47^{a}$ & $43.16 \pm 3.78^{a}$ & $52.74 \pm 12.95^{\mathrm{a}}$ & $34.01 \pm 4.76^{a}$ & $35.83 \pm 5.24^{a}$ & $68.44 \pm 16.67^{b}$ \\
\hline $\mathrm{Cd}$ & $1.43 \pm 0.19^{a}$ & $2.07 \pm 0.16^{a}$ & $2.54 \pm 0.42^{a}$ & $2.39 \pm 0.19^{a}$ & $3.22 \pm 0.39 a$ & $10.66 \pm 1.33^{b}$ \\
\hline $\mathrm{Cu}$ & $4.57 \pm 0.63^{a}$ & $3.71 \pm 0.38^{a}$ & $3.95 \pm 0.84^{a}$ & $2.95 \pm 0.32^{\mathrm{a}}$ & $3.54 \pm 0.41^{a}$ & $12.00 \pm 2.30^{b}$ \\
\hline Co & $0.95 \pm 0.15^{a}$ & $0.84 \pm 0.10^{a}$ & $1.70 \pm 0.36^{a}$ & $2.27 \pm 0.19^{b}$ & $3.21 \pm 0.39 b$ & $8.66 \pm 1.76^{b}$ \\
\hline $\mathrm{Ni}$ & $2.84 \pm 0.94^{a}$ & $5.52 \pm 3.86^{b}$ & $4.09 \pm 1.72^{a, b}$ & $1.76 \pm 0.60^{a}$ & $3.87 \pm 1.40^{a}$ & $6.22 \pm 2.32^{a, b}$ \\
\hline$A l$ & $42.90 \pm 12.89 a$ & $85.62 \pm 23.35^{a}$ & $31.20 \pm 13.33^{a}$ & $8.21 \pm 3.79 a$ & $19.05 \pm 7.08^{a}$ & $21.77 \pm 14.17^{a}$ \\
\hline$M n$ & $44.18 \pm 3.50^{\mathrm{a}}$ & $51.28 \pm 5.81^{a}$ & $46.68 \pm 11.38 \mathrm{a}$ & $28.19 \pm 4.71^{a}$ & $41.66 \pm 5.79 \mathrm{a}$ & $56.22 \pm 13.82^{\mathrm{a}}$ \\
\hline$P b$ & $5.24 \pm 0.63^{a}$ & $7.85 \pm 3.74^{a}$ & $4.41 \pm 1.31 \mathrm{a}$ & $4.32 \pm 0.85^{\mathrm{a}}$ & $4.46 \pm 0.76^{a}$ & $4.22 \pm 1.11^{a}$ \\
\hline $\mathrm{Cr}$ & $15.56 \pm 5.93^{a}$ & $32.85 \pm 8.01^{a}$ & $12.85 \pm 7.19 \mathrm{a}$ & $7.26 \pm 2.69 \mathrm{a}$ & $9.45 \pm 4.27 \mathrm{a}$ & $11.11 \pm 7.20^{a}$ \\
\hline
\end{tabular}

Letters a and $b$ show differences among stations. Data shown with different letters are statistically significant at the differences $p<0.05$ level

In the study, the highest accumulation of Fe was found at Samandağ station, $105.11 \pm 74.28 \mathrm{mg} / \mathrm{kg}$, while the lowest accumulation value for Co $(0.84 \pm 0.10 \mathrm{mg} / \mathrm{kg})$ was detected at Dörtyol station (Table 4). Although there was no significant difference in Fe concentration level between Yumurtalık and Iskenderun stations $(p>0.05)$, however, the difference in accumulation level at Dörtyol station was found significantly higher than Yumurtalık and İskenderun station $(p<0.05)$.

The concentration of $\mathrm{Zn}$ was calculated in the highest concentrations at Samandağ station, followed by Yumurtalık, Dörtyol, Payas, Arsuz, and İskenderun with $45.47 \pm 4.47 \mathrm{mg} / \mathrm{kg}$, $43.16 \pm 3.78 \mathrm{mg} / \mathrm{kg}, 52.74 \pm 12.95 \mathrm{mg} / \mathrm{kg}, 35.83 \pm 5.24 \mathrm{mg} / \mathrm{kg}$, and $34.01 \pm 4.76 \mathrm{mg} / \mathrm{kg}$, respectively (Table 4). During the study, Cd concentration was highest at Samandağ station $(10.66 \pm 1.33 \mathrm{mg} / \mathrm{kg})$, however, the concentrations of $\mathrm{Cd}$ determined were very low $(1.43 \pm 0.19 \mathrm{mg} / \mathrm{kg})$ in Yumurtalık station. The average of cadmium accumulation levels calculated from individuals in the stations are listed as follows: Samandağ $>$ Arsuz $>$ Payas $>$ İskenderun > Dörtyol> Yumurtalık.

The $\mathrm{Cu}$ concentration ranged from $2.95 \pm 0.32 \mathrm{mg} / \mathrm{kg}$ at İskenderun station to $12.00 \pm 2.30 \mathrm{mg} / \mathrm{kg}$ Samandağ, followed by Yumurtalık $(4.57 \pm 0.63 \mathrm{mg} / \mathrm{kg})$, Payas $(3.95 \pm 0.84 \mathrm{mg} / \mathrm{kg})$, Dörtyol and Arsuz. The highest $\mathrm{Cu}$ accumulation was calculated at Samandağ station $(12.00 \pm 2.30 \mathrm{mg} / \mathrm{kg})$ and the lowest $(2.95 \pm 0.32 \mathrm{mg} / \mathrm{kg})$ at İskenderun station (Table 4). The Co concentration showed the lowest value at Dörtyol station with $(0.84 \pm 0.10 \mathrm{mg} / \mathrm{kg})$ and the highest amount $(8.66 \pm 1.76$ $\mathrm{mg} / \mathrm{kg}$ ) at the station of Samandağ. Co accumulation levels order in Anemones were Samandağ > Arsuz> İskenderun> Payas> Yumurtalık> Dörtyol. The highest Ni levels were recorded at Samandağ station $(6.22 \pm 2.32 \mathrm{mg} / \mathrm{kg})$, the lowest levels were at İskenderun station $(1.76 \pm 0.60 \mathrm{mg} / \mathrm{kg})$. Higher levels of Al were observed in the muscle tissue $(85.62 \pm 23.35$ $\mathrm{mg} / \mathrm{kg})$ at Dörtyol station and was the lowest $(8.21 \pm 3.79$ $\mathrm{mg} / \mathrm{kg}$ ) at İskenderun station. Comparison with the other station's Al metal levels are listed as Dörtyol> Yumurtalık> Payas $>$ Samandağ $>$ Arsuz $>$ Iskenderun (Table 4).

$\mathrm{Mn}$ accumulation in tissues of $A$. equina was in the following order: Samandağ> Dörtyol> Payas> Yumurtalık>
Arsuz> İskenderun. The highest accumulation of $\mathrm{Mn}$ was recorded at Samandağ station. $\mathrm{Pb}$ was found to be the highest at Dörtyol station $(7.85 \pm 3.74 \mathrm{mg} / \mathrm{kg})$ and the lowest at Samandağ station $(4.22 \pm 1.11 \mathrm{mg} / \mathrm{kg})$. According to the accumulation levels of $\mathrm{Pb}$ at stations followed the order: Dörtyol $>$ Yumurtalık $>$ Arsuz $>$ Payas $>$ İskenderun $>$ Samandağ (Table 4). $\mathrm{Cr}$ was most frequently found at Dörtyol $(32.85 \pm 8.01 \mathrm{mg} / \mathrm{kg})$, and at least iskenderun station $(7.26 \pm 2.69 \mathrm{mg} / \mathrm{kg})$. The accumulation levels of $\mathrm{Cr}$ are listed as Dörtyol> Yumurtalık> Payas $>$ Samandağ $>$ Arsuz $>$ İskenderun (Table 4). In our study, it was determined that the average difference of $\mathrm{Al}, \mathrm{Mn}, \mathrm{Cr}$, and $\mathrm{Pb}$ accumulation was not significant ( $p>0.05$ ) among the stations, but $\mathrm{Cd}$ and $\mathrm{Cu}$ metal accumulation were found significantly different when compared to stations $(p<0.05)($ Table 4).

\section{DISCUSSION}

There is no information about bioaccumulation studies on the anemones in the Iskenderun Bay and even in the Northeast Mediterranean until now. Therefore, this study was also discussed in comparison with the bioaccumulation studies performed in individuals belonging to anthozoa class, which have a resident life in the of the Meditrranean and other parts of different areas and seas.

Shiber (1981) observed that the most accumulated metal in the tissues of $A$. equina individuals distributed in Lebanon was $\mathrm{Fe}(428.5 \mu \mathrm{g} / \mathrm{g}$ dry weight). Similarly, in our study, it was determined that the most accumulated metal in the muscle tissues of $A$. equina individuals distributed in İskenderun Bay was also $\mathrm{Fe}$ (105.11 mg/kg wet weight).

Samawi et al. (2018) investigated $\mathrm{Pb}, \mathrm{Cd}$, and $\mathrm{Cu}$ accumulation levels in the tissues of the Porites lutea in 3 different regions of Indonesia. In their study, the ranges of concentrations of metal accumulation in the tissues of the Porites lutea were $72.85 \pm 24.22 \mu \mathrm{g} / \mathrm{g}-102.37 \pm 21.09 \mu \mathrm{g} / \mathrm{g}$, $1.23 \pm 0.30 \mu \mathrm{g} / \mathrm{g}-1.33 \pm 0.63 \mu \mathrm{g} / \mathrm{g}$, and $2.04 \pm 0.57 \mu \mathrm{g} / \mathrm{g}-$ $2.75 \pm 0.33 \mu \mathrm{g} / \mathrm{g}$ (dry weight) for $\mathrm{Pb}, \mathrm{Cd}$, and $\mathrm{Cu}$, respectively. In our study, the lowest and highest averages of metal accumulation in the muscle tissues of the $A$. equina individuals were $4.22 \pm 1.11 \mathrm{mg} / \mathrm{kg}$ and $7.85 \pm 3.74 \mathrm{mg} / \mathrm{kg}$ 
for $\mathrm{Pb}, 1.43 \pm 0.19 \mathrm{mg} / \mathrm{kg}$ and $10.66 \pm 1.33 \mathrm{mg} / \mathrm{kg}$ for $\mathrm{Cd}$ and $2.95 \pm 0.32 \mathrm{mg} / \mathrm{kg}$ and $12.00 \pm 2.30 \mathrm{mg} / \mathrm{kg}$ (wet weight) for $\mathrm{Cu}$ were calculated. When these two studies were compared, it was found that $\mathrm{Pb}$ metal accumulated in anemones in Indonesia was higher than calculated in our study, and $\mathrm{Cd}$ and $\mathrm{Cu}$ accumulation levels were found lower. This difference is thought to be since the individuals used in both studies are not the same species and also the different pollution loads and amounts in their regions.

Corrias et al. (2020) conducted a study to determine the metal averages of $\mathrm{Al}, \mathrm{Cd}, \mathrm{Cr}, \mathrm{Cu}$, and $\mathrm{Fe}$, which show accumulation in sea anemone Anemonia sulcata in 6 different stations of the Mediterranean region of Sardina. They calculated that the highest accumulation was $\mathrm{Fe}$ $(80.828 \pm 24.108 \mathrm{mg} / \mathrm{kg})$ and the lowest accumulation was $\mathrm{Cd}$ $(0.002 \pm 0.003 \mathrm{mg} / \mathrm{kg})$. Also, they reported that the metal order in descending order was $\mathrm{Fe}>\mathrm{Al}>\mathrm{Cu}>\mathrm{Cr}>\mathrm{Cd}$. When compared with our study ( $\mathrm{Al}, \mathrm{Cd}, \mathrm{Cr}, \mathrm{Cu}$ and $\mathrm{Fe})$, it was determined that the highest accumulation was $\mathrm{Fe}$ and the lowest accumulation was $\mathrm{Cd}$ in the muscle tissues of $A$. equina individuals. In our study, the metal ranking showing accumulation in muscle tissue was calculated as $\mathrm{Fe}>\mathrm{Al}>\mathrm{Cr}>\mathrm{Cu}>\mathrm{Cd}$.

Escobar-Chicho et al. (2019) found the levels of metal accumulation in different tissues of an anemone (Paraphelliactis pabista) in the Gulf of California Guaymas basin at $501.15 \mathrm{mg} / \mathrm{kg}, 132.35 \mathrm{mg} / \mathrm{kg}, 9.94 \mathrm{mg} / \mathrm{kg}, 0.24 \mathrm{mg} / \mathrm{kg}$, $3.21 \mathrm{mg} / \mathrm{kg}, 645.79 \mathrm{mg} / \mathrm{kg}, 136.28 \mathrm{mg} / \mathrm{kg}, 23.46 \mathrm{mg} / \mathrm{kg}, 8.86$ $\mathrm{mg} / \mathrm{kg}$ (dry weight) $\mathrm{Fe}, \mathrm{Zn}, \mathrm{Cu}, \mathrm{Co}, \mathrm{Ni}, \mathrm{Al}, \mathrm{Mn}, \mathrm{Pb}$, and $\mathrm{Cr}$, respectively. When the accumulation levels of $A$. equina individuals distributed in the bay were compared, it was determined that $\mathrm{Zn}, \mathrm{Cu}, \mathrm{Co}, \mathrm{Ni}, \mathrm{Mn}$, Cr levels were higher than other studies, whereas $\mathrm{Fe}, \mathrm{Al}, \mathrm{Pb}$ accumulation levels were lower than other studies. The reason for this is thought to be due to the difference in the anemone species used in the two studies and the geographical difference.

Lozano-Bilbao et al. (2020) investigated that the heavy metal accumulation levels in the muscle tissue of Anemonia sulcata individuals in 6 different regions of the Canary Islands.

\section{REFERENCES}

Anonymous, (1997). Türkiye Kıyılarındaki Lagünlerin Yönetim ve Geliştirilme Stratejileri ve Islahı. 1. Cilt. Tarım ve Köy İşleri Bakanlığı Tarımsal Üretim ve Geliştirme Genel Müdürlüğü, 578.

Anonymous, (2008). Toksikoloji. Trakya Üniversitesi Fen Fakültesi, Biyoloji Bölümü, Ders Notları.

Can, M.F., Yılmaz, A.B. \& Mazlum, Y. (2019). A Meta-Analysis: Geo-statistical approach on the $T H Q$ values of $\mathrm{Cu}, \mathrm{Zn}$, and Fe accumulation in some fish species from İskenderun Bay, North-Eastern Mediterranean. V. International Congress on Natural and Health Sciences (ICNHS-2019), 69-89.

Chintiroglou, C.H. \& Koukouras, A. (1992). The feeding habits of three Mediterranean sea anemone species, Anemonia viridis (Forskal), Actinia equina (Linnaeus) and Cereus pedunculatus (Pennant), Helgol. Meeresunters., 46, 53-68.

Corrias, F., Atzei, A., Addis, P., Secci, M., Russo, M. \& Angioni, A. (2020). Integrated environmental evaluation of heavy metals and metalloids
As a result of the study, the highest metal accumulation level of $A$. sulcata in muscle tissue was reported as $25.264 \pm 27.185$ $\mathrm{mg} / \mathrm{kg}$ and $0.058 \pm 0.050 \mathrm{mg} / \mathrm{kg}$ for $\mathrm{Pb}$ and $\mathrm{Cd}$ metals, respectively. As a result of our study, the highest metal accumulation levels calculated in muscle tissue were determined as $7.85 \pm 3.74 \mathrm{mg} / \mathrm{kg}$ and $10.66 \pm 1.33 \mathrm{mg} / \mathrm{kg}$ for $\mathrm{Pb}$ and $\mathrm{Cd}$, respectively. When our study is compared with this study, the reason for the difference in the results is that the bays where the studies are conducted are exposed to different sources of pollution.

\section{CONCLUSION}

The accumulation levels of heavy metals ( $\mathrm{Fe}, \mathrm{Zn}, \mathrm{Cd}, \mathrm{Cu}$, $\mathrm{Co}, \mathrm{Ni}, \mathrm{Al}, \mathrm{Mn}, \mathrm{Pb}$, and $\mathrm{Cr}$ ) in $\mathrm{A}$. equina, which is a common anemone species for İskenderun Bay, were determined in six stations where different pollution discharges were observed in the İskenderun Bay. It was determined that the highest Fe accumulation level was obtained at Samandağ station, while the lowest accumulation value for Co was found at Dörtyol station. Metal concentrations accumulating in the muscle tissue of $A$. equina individuals are in descending order; $\mathrm{Fe}>\mathrm{Zn}>\mathrm{Mn}>$ $\mathrm{Al}>\mathrm{Cr}>\mathrm{Cu}>\mathrm{Pb}>\mathrm{Ni}>\mathrm{Cd}>\mathrm{Co}$. In addition, this study is the first detailed bioaccumulation study conducted with $A$. equina in İskenderun Bay. In this study it is predicted that $A$. equina species can be used in biomonitoring studies due to reasons such as having a stable (silent) life somewhere, having a lifespan of about 3 years, accumulating metals in the environment and easily and to accumulate metals from the sea and to distribute the animal in the stations where the study is carried out in İskenderun Bay. In order to determine which metal contaminant is at which station, sea water samples should also be taken and analyzed as well as anemone samples. Another issue is that, since each station has more than one pollution source, it is very difficult to say which of the industrial activities that emit similar metals are more effective in these pollution values. Maybe another future study or studies investigating which of these different loads are more effective may be the subject of the new study.

bioaccumulation in invertebrates and seaweeds from different marine coastal areas of Sardinia, Mediterranean Sea. Environmental Pollution, 266, 115048.

Denny, M.W. \& Gaines, S.D. (2007). Encyclopedia of tidepools and rocky shores, Berkeley: University of California Press.

Duysak, Ö. \& Ersoy, B. (2014). A biomonitoring study: heavy metals in Monodonta turbinata (Mollusca: Gastropoda) From Iskenderun Bay, North-Eastern Mediterranean. Pakistan Journal of Zoology, 46, 13171322. DOI: 0030-9923/2014/0005-1317

Duysak, Ö. \& Azdural K. (2017). Evaluation of heavy metal and aluminium accumulation in a gastropod, Patella caerulea L., 1758 in Iskenderun Bay, Turkey. Pakistan Journal of Zoology, 49, 629-637. DOI: 10.17582/journal.pjz/2017.49.2.629.637

Ekici, H. \& Yarsan, E. (2009). Akuakültür canlılarında zehirli etki oluşturabilecek maddeler. E. Ü. Su Ürünleri Dergisi, 26, 229-233. 
Escobar-Chicho, M., Soto, L.A., Vanegas-Pérez, C. \& Estradas-Romero, A. (2019). Heavy metal bioaccumulation in the anemone Paraphelliactis pabista Dunn, 1982 (Actiniaria: Hormathiidae) from the Hydrothermal System of Guaymas Basin, Gulf of California. Bulletin of Environmental Contamination and Toxicology 102, 486-491. DOI: $10.1007 / \mathrm{s} 00128-019-02588-z$

Fish J.D. \& Fish, S. (2011) A student's guide to the seashore. Cambridge University Press. Cambridge.

Gadelha, J.R., Ferreira, V.A.M., Abreu, S.N., Soares, A.M.V.M. \& Morgado, F.M.R. (2010). Experimental mercury bioaccumulation trends in sea anemone Actinia equina exposed to chlor-alkali industry effluent contaminated water. Interdisciplinary Studies on Environmental Chemistry, 3, 149-157.

Harland, A.D., Bryan, G.W. \& Brown, B.E. (1990). Zinc and cadmium absorption in the symbiotic anemone Anemonia viridis and the nonsymbiotic anemone Actinia equina. Journal of the Marine Biological Association of the United Kingdom, 70, 789-802. DOI: $10.1017 / S 0025315400059063$

Kosswig, C. (1953). Türkiye balıkçlığının bazı biyolojik veçheleri. Hidrobiyoloji Mecmuası, 1(4), 145-153.

Lozano-Bilbao, E., Espinosa, J.M., Lozano, G., Hardisson, A., Rubio, C., González-Weller, D. \& Gutiérrez, Á.J. (2020). Determination of metals in Anemonia sulcata (Pennant, 1777) as a pollution bioindicator. Environmental Science and Pollution Research, 23, 1-7. DOI: $10.1007 / \mathrm{s} 11356-020-08684-6$

Ormond, G.F.R. \& Caldwell, S. (1982). The effect of oil pollution on the reproduction and feeding behaviour of the sea anemone Actinia equina. Marine Pollution Bulletin, 13,118-122.

Perrin, M.C., Thorpe, J.P. \& Sole-Cava, A.M. (1999). Population structuring, gene dispersal and reproduction in the Actinia equina species group. Oceanography and Marine Biology, An Annual Review, 37, 129-152.

Phillips, D.J.H. \& Segar, D.A. (1986). Use of bioindicators in monitoring conservative contaminants-programme design imperatives. Marine Pollution Bulletin, 17, 10-17. DOI: 10.1016/0025-326X(86)90797-6
Rainbow, P.S. \& Phillips, D.J.H. (1993). Cosmopolitan biomonitors of trace metals. Marine Pollution Bulletin, 26, 593-601. DOI: $10.1016 / 0025-326 \times(93) 90497-8$

Samawi, M. F., Werorilangi, S., Tambaru, R. \& Rastina, R. (2018). Accumulation of heavy metals within hard coral Porites lutea in Spermonde Archipelago, South Sulawesi. Jurnal IImu Kelautan Spermonde, 4(1), 39-42.

Shiber, J. G. (1981). Metal concentrations in certain coastal organisms from Beirut. Hydrobiologia, 83(2), 181-195

Simsek, E. \& Demirci, A. (2018). Barotrauma treatment effects on survival rates for some discarded fish by trawl fishery. Fresenius Environmental Bulletin, 27 (7), 4867-4873.

Sole-Cava, A.M. \& Thorpe, J.P. (1992). Thorpe, Genetic divergence between colour morphs in populations of the common intertidal sea anemones Actinia equina and A. prasina (Anthozoa: Actiniaria) in the Isle of Man. Marine Biology, 112(2), 243-252. DOI: 10.1007/BF00702468

Türkmen, A. \& Türkmen, M. (2005). Seasonal and spatial variations of heavy metals in the spiny rock osyster, Spondylus spinosus, from coastal waters of İskenderun Bay, Northern East Meditteranean Sea, Turkey. Bulletin of Environmental Contamination and Toxicology, 75, 716-722. DOI: $10.1007 / \mathrm{s} 00128-005-0810-0$

Tüzen, M. (2003). Determination of heavy metals in fish samples of the middle Black Sea (Turkey) by graphite furnace atomic absorption spectrometry. Food Chemistry, 80: 119-123. DOI: $10.1016 /$ S0308-8146(02)00264-9

Volterra, L. \& Conti, M.E. (2000). Algae as biomarkers, bioaccumulators and toxin producers. International Journal of Environment and Pollution, 13 , 92-125. DOI: 10.1504/IJEP.2000.002312

Yüzereroğlu, T.A., Gök, G., Çoğun, H.Y., Firat, O., Aslanyavrusu, S., Maruldalı, O. \& Kargin, F. (2010). Heavy metals in Patella caerulea (Mollusca, Gastropoda) in polluted areas from the İskendeurn Gulf (Mediterranean Turkey). Environmental Monitoring and Assessment, 167, 257-264. DOI: 10.1007/s10661-009-1047-x

Zar, J.H. (1984). Biostatistical analysis. Second edition. Prentice Hall, Int., New Jersey, $718 p$. 